\title{
The church and society in South Africa celebrating first ten years of democracy (1994-2004)
}

\author{
R T H Dolamo \\ (University of South Africa)
}

\section{ABSTRACT}

\section{The church and society in South Africa celebrating first ten years of democracy (1994-2004)}

In this article, colonialism, slavery, racism and apartheid are singled out as scourges that have afflicted South Africans for over three-andhalf centuries in respect of the first four scourge, and for four-andhalf decades in respect of apartheid. Against this backdrop, the struggles of the people of South Africa against these scourges are portrayed and analysed. With the attainment of freedom and democracy in 1994, the ANC led government enacted pieces of legislation whose aim was to deepen and broaden democracy, thereby transforming the society beyond recognition of how it was before 1994. Celebrating the first ten years of freedom and democracy, the people of South Africa are taking stock of what has been achieved and not achieved and bracing themselves for the challenges that are facing them into the second decade.

\section{INTRODUCTION}

Racial injustices against blacks in South Africa by the colonisers dates back to 1652. This phenomenon of oppression, dispossession and exploitation was firmly entrenched in 1948 when the apartheid government took office from the British. But since the unbanning of political organisations that resisted apartheid and fought for the national political liberation in 1990 and with the release of political leaders such as Nelson Mandela and particularly with the attainment of democracy in 1994, serious attempts have been made to address these historical racial justicese experienced by blacks.

In 2004 South Africa's democracy completed its tenth year and celebrations were planned throughout the country. The ANC led government gave a report on what it has done in the exercise of power that majority of South Africa's people have entrusted to it. Our third general elections were conducted on the 14 April 2004 and the African National Congress won the elections attaining almost $70 \%$ of the votes. The ANC even won victory in the two provinces that have eluded them in the past ten years namely, KwaZulu-Natal 
and the Western Cape. President Thabo Mbeki was sworn in for a second term on the 27 April 2004 as president of the Republic of South Africa.

\section{RACISM AND DEVELOPMENT OF THE APARTHEID POLICY}

It seems that inspite of independence, racism still remains a problem in most, if not all, British colonies. In Africa, Australia and Asia stories of white racism against the indigenous peoples abound. Of course, other colonial powers such as Portugal also practised the segregation policy, as Mzimela says: "Everywhere where people have been colonised, they have been economically exploited, politically oppressed, and racially discriminated against" (Mzimela 1983:112).

Racial segregation was not merely a separation of colonisers and the colonised, but a policy aimed at ensuring white supremacy and survival. Davenport (1987:315-338) points out that, as early as 1905, Sir Godfrey Lagden, who was given a task of working out a policy for Natives recommended a complete and permanent separation of blacks and whites, politically and territorially. When apartheid was legalised in 1948, racism had already taken root as Nolan (1988:72) aptly observes. Motsoko (1984) indicates that blacks had lost practically everything by 1881 . That included land, wealth, political power, national sovereignty, and even human dignity. Well before the establishment of the apartheid state in South Africa, many laws against blacks had been promulgated. The foundation was provided by the British Parliament that promulgated the Union of South Africa Act of 1909, an act that excluded blacks from the envisaged Union of South Africa. Blacks were handed over by Britain to the white minority government, along with black land and black-owned mineral resources (Motsoko 1984:75).

Certain jobs, especially in the mines, were reserved for whites, and by 1912 it had become illegal for blacks to strike. The Natives (Urban Areas) Act of 1923 regarded blacks as migratory workers in the cities, because racial intermingling had been regarded as undesirable. The Natives Act of 1927 was taken further in 1937 by controlling the influx of blacks into the cities, and by making provision for unrequired black labour to be removed to the homelands. The Land Acts of 1913 and 1936 completed the dispossession of black owned land by the whites. It was estimated 
that $87 \%$ of South Africa was in white control, and whites made up only $20 \%$ of the total population of South Africa. Most of the $13 \%$ of the land given to blacks was arid and rocky (Davenport 1987; Lodge 1983; Brotz 1977).

Several laws were passed through parliament in order to discriminate against blacks. Between 1948 and 1960, overtly discriminatory and harsher repressive laws were promulgated. Davenport calls this period, "The Age of Social Engineers" (Davenport 1987:361). Population groups were categorised into biological sections, and residential areas were allocated in accordance with the segregation policies. The Prohibition of Mixed Marriages Act of 1949 prohibited marriages between the black and white races. This was followed by the Population Registration Act of 1950 that made provision for race classification. The Immorality Act of 1927 was tightened by closing all other loopholes and making prosecution of offenders easier by accepting unsubstantiated evidence. Group Areas Bills were passed by Parliament in 1950 . These were supported by the Separate Amenities Act, Act 49 of 1953. An attempt was made to prohibit even interracial church services through Clause 29 (c) of the Natives Laws Amendment Bill of 1957. Mission education was discouraged and undermined through The Bantu Education Act, Act 47 of 1953. To put blacks at an economic disadvantage, the Native Labour (Settlement of Disputes) Act, Act 48 of 1953 as amended in 1973 and 1976, prohibited formation of black trade unions. The Promotion of Bantu Self-Government Act of 1959 was promulgated, by which ethnic groups would be allocated some land on which to govern themselves; it was the birth of Bantustans. In 1957 "Die Stem van Suid-Afrika" was declared the only national anthem for the Union (Mzimela 1983; Davenport 1987; Lodge 1983; Government Gazettes).

One may call the next stage that started from 1960 the age of social implementation. Laws that had been formulated until 1960 were to be enforced and strictly administered. Loopholes that manifested themselves during the application and administration of the laws were closed and the screws tightened even more. As protests increased in number and intensity, government outlawed the African National Congress (ANC) and the Pan Africanist Congress (PAC) in 1960 and declared the first state of emergency in the land. The South African Communist Party (SACP) had already dissolved 
itself in 1950 when communism was declared public enemy number one. "Communists", a term that referred to all those who were critical of apartheid, were hunted down. It became common to speak of South Africa as a police state. For example, in 1962, police could detain suspects for up to twelve days without charging them. In 1965 suspects were detained for up to hundred-and-eighty days, and by 1976 such suspects could be detained indefinitely. Police were socalled "political" police. They assisted the army in the crushing of demonstrators. In 1960, sixty-nine people were shot dead (many from behind), and thousands were injured in Sharpville. In June 1976 Soweto pupils marched in protest against Afrikaans as a medium of instruction and also against the whole Bantu Education system. The police killed hundreds of students. Thousands were injured and many more were unaccounted for. Four successive states of emergency were declared until the beginning of 1990. Blacks and whites began to hate each other as these racial laws were acted upon.

The next step was introduction of homeland system policy. Blacks were divided according to their ethnic groups. For example, territorial separation was implemented with the view to denying blacks their South African citizenship. Transkei became the first homeland to obtain self-government status from Pretoria and others followed. The Bantu Homeland Citizenship Act of 1970 sought to attach every black person to a specific homeland. This meant that, upon a particular homeland becoming "independent" from South Africa, all blacks who might be identified with that homeland, would automatically lose their South African citizenship. A Coloured Persons' Representative Council was legislated in 1968 to take care of the so-called Coloureds' political needs. To ensure that interracial political organisations also followed the policy of apartheid, the Prohibition of Political Interference Act of 1968 was passed, with the result that the Liberal Party soon dissolved. The Affected Organisations Bill of 1974 declared certain organisations illegal and foreign funding was stopped. The National Union of South African Students (NUSAS) and the Christian Institute of South Africa (CI) were declared illegal. Many black consciousness-orientated organisations including the newspaper "World" were banned on 19 October 1977. More than 5980 people were detained between 16 June 1976 and 28 February 1977. Some were not very lucky for they died in detention such as Steve Biko who died on 12 September 1977 as result of police brutality. In spite of the crackdown on 
government critics, the 1980s were turbulent to such an extent that in July 1985 a state of emergency was declared in thirty-six magisterial districts of South Africa. It was partially lifted, only to be reimposed countrywide in June 1986 until early 1990 (Davenport 1983: Government Gazette)

\section{THE CHURCH STRUGGLE AGAINST APARTHEID}

The reaction from the churhes was interesting. For example, theology and the spirituality of the struggle were developed in South Africa by the churches, especially by those who were members of the South African Council of Churches and the Roman Catholic Church, as well as other faiths such as Judaism and Islam. Individuals also in their private capacities and other organisations worked fearlessly for justice, epecially those whose churches and faith traditions were openly pro-apartheid. For brevity, I will restrict my study to the activities of the SACC member churhes which was formerly known as Christian Council of South Africa before 1960.

The Cottesloe Conference which was prompted by the aftermath of Sharpeville set the scene for a showdown with the aparheid government. Apartheid was for the first time confronted as a racial issue. The Afrikaans speaking churches such as the Nederduits Hervormde Kerk and Dutch Reformed Church withdrew from the ecumenical body in protest. They felt that the SACC was backing communism, especially the ANC and PAC.

Following the Cottesloe Statement, a prophetic message was issued in 1968 by the SACC entitled, "A message to the people of South Africa". This message offered a more theological and bold rejection of apartheid and racism. In a summary form, the message was "that apartheid was condemned as a false faith and a heresy that worked against the teachings of Christ on love and against the Holy Spirit's work of reconciliation" (Villa-Vicencio 1986:214).

As the struggle intensified, so did the brutality of the police state grew against the agents of change, with the introduction of a successive states of emergency between 1984 and 1990. In September 1985, a group of concerned theologians in South Africa, known as the Kairos theologians, meditated on the escalating confrontation between the government and the oppressed. According to them, the moment of truth had arrived: If blacks wanted liberation, it would not be given to them, they had to seize it and wrestle it from the white minority regime. Hard on the heels of the 
Kairos Document was the publication of the Road to Damascus Document in 1989. It insisted that repentance should be linked to restitution, otherwise genuine recociliation would not be possible.

The 1974 SACC annual conference held in Hammanskraal deliberated on the question of conscientious objection to military conscription, among other issues such as economic sanctions against the country. It was then compulsory for all white males to be consripted. South African Christians were called upon to refuse to serve in the army and churches were also urged to review the basis on which they appointed chaplains to the army. The government reacted to the call by introducing a Defence Further Amendment Bill, section 121(c) of 1977 Act to curb the activities of the advocates of conscientious objection.

Some theologians, especially those associated with the Kairos Document, called for the overthrow of the white regime since according to them, it had lost its moral and theological legitimacy to govern, if it ever had that legitimacy. The Church in fact prayed for the downfall of the government and collaborated with some of the forces which were bent on removing it from power. No wonder that some embraced the aims and ideals of the Programme to Combat Racism, a WCC generated document which supported financially the activities of the liberation movements of Southern Africa (Mbali 1987). As the struggle continued, whites began to realize that life was changing and South Africa entered a new phase.

\section{ATTAINMENT OF FREEDOM AND DEMOCRACY}

It became clear to the apartheid government that survival of whites depended on the freedom of blacks. President F W de Klerk started dealing with the issue of change. He announced in Parliament on 2 February 1990 that outlawed political organisations such as the African National Congress, the Pan Africanist Congress and the South African Communist Party would be unbanned. Of great national and international consequence was that Nelson Mandela would unconditionally be released from prison on 11 February 1990.

Once prisoners had been released and exiles had returned home, serious talks started between the government and the liberation movements leading to multiparty talks known as the Convention for a Democratic South Africa (CODESA). With negotiations being conducted at a painful snail's pace, and at times breaking down of talks were experienced and later being restarted. 
An agreement was reached in principle to install a five-year Government of National Unity (GNU) in which all parties polling five percent and over in the envisaged general elections would proportionally be represented in government and cabinet. The establishment of the Transitional Executive Council would ensure and supervise arrangement for the first democratically conducted elections in the country, which took place in April 1994. Nelson Mandela was inaugurated as South Africa's first democratically elected head of state in May 1994.

New life began for all South Africans. No one was to be discriminated against and a new government began functioning. Two of the most important tasks of Mandela's government were to write a new Constitution and enact laws that would redress the historical imbalances of the past.

The inauguration of the Government of National Unity on the 10 May 1994 was done in accordance with the provisions of the interim Constitution of which the chief aim was to deracialise South Africa (Basson 1994).

\section{(a) The Constitution of the Republic of South Africa, 1993 (Act 209 of 1993)}

With the constitutional agreements reached among the political parties and other stakeholders, the abovementioned Constitution would be written as an interim measure that would hold together a government of national unity after the first democratic elections of April 1994. The preamble is unambiguous in its intention:

"... a need to create a new order in which all South Africans will be entitled to a common South African citizenship in a sovereign and democratic constitutional state in which there is equality between men and women and people of all races so that all citizens shall be able to enjoy and exercise their fundamental rights and freedoms".

(b) The Constitution of the Republic of South Africa, 1996 (Act 108 of 1996)

This is definitely a refined version of the abovementioned interim Constitution. We shall focus our attention on the Constitution per se. Chapter 1, "Founding Provisions" states in section 1: "The Republic of South Africa is one, sovereign, democratic state founded on the following values: 
i) Human dignity, the achievement of equality and the advancement of human rights and freedoms;

ii) Non-racialism and non-sexism;

iii) Supremacy of the constitution and the rule of law;

iv) Universal adult suffrage, a national common voters roll, regular elections and a multiparty system of democratic government, to ensure accountability, responsiveness and openness".

In section 2 on the supremacy of the Constitution it is stated,

"This Constitution is the supreme law of the Republic; law or conduct inconsistent with it is invalid, and the obligations imposed by it must be fulfilled".

(c) Land Restitution and Reform Laws Amendment, 1997 (Act 63 of 1997)

The government took seriously the issue of black land dispossession by colonisers. To this end, the Act was enacted

To provide for restitution of rights in the land to persons or communities dispossessed of such right after 19 June 1913 as a result of past racially discriminatory laws of practices.

"Redress" could be approached in either two ways, namely the granting of an appropriate right in alternative state-owned land and the payment of compensation, and "restitution" would mean the restoration of right in land or equitable redress. To make the implementation possible, the Act provides for establishment of a Commission on Restitution of Land Rights whose function, among others, would be to investigate claims and to mediate and settle disputes arising from such claims, and to refer claims to the Claims Court and the Land Claims Court whose chief functions would be to determine a right to restitution of any right in land and to approve compensation payable. About 40,000 applications out of an estimated 62,000 have been settled and the government hopes to settle all the applications by 2005 .

\section{(d) Labour Relations Act 19951 (Act 66 of 1995)}

Although slavery was abolished in South Africa in the early 1830s, blacks have been working under harsh conditions and earning slave wages. The promulgation of the Act was to correct and change the status quo. Farm workers, domestic servants and public sector workers, and several other subcategories of employees, are also 
protected under the Act. However, excluded by the Act are members of National Defence Force, National Intelligence Agency and South African Secret Services as well as certain categories that provide essential services.

Three statutory bodies have been put in place to facilitate and to ensure the implementation of the law, namely the Commission for Conciliation, Mediation and Arbitration, the Labour Court as well as their Labour Appeal Court. These were created in order to protect human rights.

Strengthening the arm of this Act was the enactment of the Basic Conditions of Employment Act 1997 (Act 75 of 1997) which "...give effect to the right to fair labour practices referred to in section 23(1) of the Constitution by establishing and making provision for the regulation of basic conditions of employment...". Of utmost importance is the outlawing of employment of children and forced labour. The Employment Conditions Commission has been established to conduct public hearings assisted by labour inspectors by monitoring the labour market and by forcing legally the observance of the terms of the law and its determinations. As a result of discrimination, blacks were not able to participate in economical affairs of South Africa. This issue had to be addressed.

\section{(e) Employment Equity Act 1998 (55 of 1998)}

Central to the legislation is the issue of affirmative action outlined in chapter 3 of which its measures are as follows:

"Affirmative action measures are measures designed to ensure that suitably qualified people from designated groups have equal employment opportunities and are equitably represented in all occupational categories and levels in the workforce of designated employer".

(f) Broad-Based Black Economic Empowerment Act 2003 (53 of 2003)

Among other functions of this Act is "To establish a legislative framework for promotion of black economic empowerment; to empower the Minister to issue codes of good practice and to publish transformation charters... 
(g) Unemployment Insurance Amendment Act 2003 (32 of 2003)

Domestic and farm workers were not adequately covered by the Labour Relations Act in terms of basic wages and other benefits. This Act addresses these issues. Otherwise before the promulgation of the above mentioned Act together with the Skills Development Amendment Act, 2003 (no 31 of 2003), which encourages learnerships, employers of such categories of workers could hire and fire and pay their workers whatever wages they wished. But now these workers should get benefits such as unemployment insurance, including pensions.

\section{(h) Promotion of National Unity and Reconciliation Act, 1995 (Act 34 of 1995)}

One of the most important pieces of legislation passed in parliament in building a new society was the enactment of the above mentioned Act whose aim was to promote healing and reconciliation among perpetrators and victims of political violence committed between 01 March 1960 and 08 October 1990. Successes and failures of this exercise are contained in the Commission's interim report of 1998 and the final report of 2003. But the overall objectives have been realised. People such as Gideon Nieuwoudt who were refused amnesty are being prosecuted for their apartheid era crimes and atrocities. This is how the new South Africa was created, creating peace and reconciliation.

\section{ELECTION PROMISES}

When Nelson Mandela appealed to South Africa to vote for the ANC during the 1994 general elections, he promised them a South Africa in which people will live in peace and with equal opportunities in a document entitled "A Better life for All". A policy document was produced known as "Reconstruction and Development Programme" (RDP 1994) in which means and ways are outlined by which the ANC together with its alliance partners would realise its vision. To demonstrate that the ANC was serious about poverty alleviation, empowerment and indeed transformation of the society, when it formed government, a cabinet minister without portfolio later was appointed to facilitate and oversee the programme. Unfortunately this ministry was abolished. 
The pieces of legislation, including the country's Constitution discussed above, indicate to us that the State through the ANC dominated government of national unity was seriously concerned about inequalities and injustices of the past. Labour that comprises the majority of blacks has relatively been empowered whilst at the same time the fears of big business have been sufficiently allayed. The ANC promised to create 500000 jobs and build a million houses during its term in office, but unfortunately the promises especially on poverty alleviation were not accurately costed. In addition the government inherited apartheid debt of about US \$250 billion. In fact, the poverty crisis has deepened.

The ANC in its second term of governing was not able to reach all of its goals but nonetheless continued to struggle to address problems faced by the people. One is of the view that the ANC-led government failed the people of South Africa because it turned its back on two crucial fundamental policies, namely nationalisation and market protectionism.

\section{(i) Nationalisation}

It has been the policy of the ANC as a liberation movement and its alliance partners to nationalise State assets and property and thereby regulate the distribution of wealth among the people. The Freedom Charter says in Nolan (1988:222),

"The national wealth of our country, the heritage of all South Africans, shall be restored to the people; the mineral wealth beneath the soil, the banks and monopoly industry shall be transferred to the ownership of the people...".

Nelson Mandela reiterated this policy in his first speech after his release from prison on the 11 February 1990 at Bishops' Court, Cape Town. In his preface to the RDP document (1994) Mandela says, "In preparing the document, and taking it forward, we are building on the tradition of the Freedom Charter".

During his 1996 travels abroad, especially in Europe and the USA, Mandela announced a policy change that dismayed and shocked the ANC alliance partners notably the Congress of the South African Trade Unions (COSATU) and the SACP, namely that the ANC led government would abandon nationalisation and embrace privatisation. Key State assets such as railways, airways and telecommunications and parastatals such as Eskom, Iscor, Sasol 
and Telkom would be privatised. Once privatised, these corporations adopted policies such as rationalisation, right sizing and downsizing, which are actually euphemisms for retrenchment. No wonder that 1994 to 1998 saw job losses of up to 500000 . This year, five million out of an estimated forty million South Africans are unemployed and lots more are underemployed.

\section{(ii) Adoption of free market policies}

Directly linked to privatisation is the concept of globalization. The ANC promised South Africans protection against unfair trading and commercial competition from outside. The Freedom Charter (see Nolan 1988:22) says, "All people shall have equal rights to trade where they choose, to manufacture and to enter all trades, crafts and profession".

But how will this dream be realised if South Africa in its democratic infancy is already open to world markets? George Soros caused economic sorrows in 1992 when he bashed the Bank of England and caused the Chancellor of the Exchequer to lose his job (Blow 1998:2). We witnessed towards the end of 1997 the fall of the so-called Asian tigers such as Malaysia and Thailand, the Asian economic giants regarded as success stories by the IMF and the West. South Africa seems to have bought into this "success-story" myth. Virtually anybody from anywhere can buy property in South Africa. As airways such as Fly Star and Sun Air went in liquidation, outside companies have moved in to buy them. An instrument being used to apply both privatisation and globalization was the macroeconomic strategy known as "Growth, Employment and Redistribution" (GEAR) adopted by the government in June 1996. Bullard writes, "SA went to market and cried all the way home" (1998:19), and Vally also is unambiguous, "SA's Gear to national suicide. We live in the shadow of Gear which, far from transforming society, it widens the rich-poor gap (1999:15).

In his address to the nation when opening Parliament on February 6, 2004, Mr Mbeki did admit that poverty had deepened and millions were unemployed, but promised that conditions would improve. Minister of Finance Trevor Manuel, when delivering his $2004 / 5$ budget speech on the $18^{\text {th }}$ of February, also indicated the successes and failures of the past ten years and challenges that faced government in the future. He indicated, for example, that the government has been able to reduce the 1992/3 deficit of $9 \%$ to $3.1 \%$ 
and that the apartheid debt has been reduced quite considerably. According to critics from the civil society and non-governmental organisations, including the churches, however, social deficit has increased to unacceptable levels, and they challenged the government to concentrate on social and welfare provision in the next ten years. Inspite of these problems, the new South Africa continues to grow and address these problems.

\section{BUILDING ON THE SUCCESSES}

In spite of the problems indicated above, there are still many reasons to celebrate our ten years of democracy, especially if the government is prepared to learn from the constructive criticisms and critique given so far.

i) South Africa is a democracy at last and we must protect and nurture it by respecting the Constitution.

ii) South Africa belongs to all who live in it. The Land Restitution and Reform Laws Act has succeeded in restoring land to some of its original owners who lost it since 1913, or have given compensation to victims of uprooting. (But the government should stretch this 1913 limitation back to 1652).

iii) Labour Relations Act and other Acts have strengthened the workers' power base and have increased their ownership of labour; the exploitation of farm workers and domestic workers is no longer tolerated.

iv) The Employment Equity Act has addressed the question of groups who have been historically marginalised in the workplace, such as blacks and women, by legislating for affirmative action measures. Giant black and women empowerment corporations and projects have been established.

v) South Africa must pressure the international community to write off the apartheid debt. It is not only a theological imperative to do so, but also a moral imperative. Apartheid debt is blood money.

\section{A THEOLOGICAL REFLECTION AND CONCLUSION}

As the Church led us to liberation, we need to go back to the basics.

Jesus of Nazareth came to explain for us through his teachings, parables, miracles and his life, the real nature and meaning of power namely, that power, political or otherwise exercised, collectively or individually, is service. He used his authority and influence to bring 
the message across and most importantly he led by example. According to an ancient hymn recorded in Philippians 2:4-11, Jesus did not wish to be served. When the sons of Zebedee came to him to look for positions of power when Jesus would inaugurate his rulership, he answered by telling them that such positions entailed humility and service as the most powerful people would become the lowliest of all (Mk 10:35-4; Lk 22:24-27). During his Last Supper Jesus washed the feet of his disciples, a task that was customarily done by servants or slaves in a household. This is a challenge to anyone who wants to be a leader.

It is ironical that the apartheid regime that claimed to be Christian, abused its power to privilege the white minority at the expense of the black majority, whereas a democratic regime which is a self-confessed secular state was and is more inclusive of all South Africans, black and white, in its exercise of power. This secular state whose founders were regarded as atheists and communists has done a lot in the short space of time of ten years to restore our dignity as individuals and as a nation.The Freedom Charter in fact declares that South Africa belongs to all who live in it, black and white. Two opposite paradigms are noticeable in South Africa's socio-political history. One that used power as force, and the other that uses power as a tool for service and delivery to all South Africans irrespective of race, creed or sex. Our hope and prayer is that South Africa will become a model democracy steeped in promoting and protecting human rights. If what we see unfolding before us is anything to go by, we should look forward to another decade that is full of optimism and hope, not only for South Africa, but also for the continent as a whole through the African Union and the New Partnership for Africa`s Development.

Lastly, I implore the churches and theologians in South Africa to play a more active role in their prophetic and pastoral ministries during the second decade of democracy than they did in the previous one. Church and State relations, even in a democratic order such as ours, should of necessity be in a creative tension. Finally, South Africans are challenged to help poor countries in good governance. It is our global and specifically continental responsibility to assist other nations without imperialistic agenda. 


\section{Consulted literature}

ANC 1994. A Better Life for All. Johannesburg: Department of Information and Publicity.

ANC 1994. The Reconstruction and Development Programme. Johannesburg: Umanyano Publication.

Basson D 1994. South Africa `s Interim Constitution. Cape Town: Juta \& Co.

Blow D 1998. City Press News. July 5, 2.

Brotz H 1977. The Politics of South Africa. London: Oxford University Press.

Bullard D 1998. Sunday Times. Sunday Analysis. July 5, 19.

Davenport T R H 1987. South Africa. A Modern History. London: Macmillan Press.

Government Gazzetes.

The Constitution of the Republic of South Africa 1993 (Act 209 of 1993).

The Constitution of the Republic of South Africa 1996 (Act 108 of 1996).

Lodge T 1983. Black Politics in South Africa Since 1945. Johannesburg: Ravan Press.

Mbali Z 1987. The Churches and Racism. London: SCM.

Motsoko P 1984. Apartheid: The Story of a Dispossessed People. London: Marriam Books.

Mzimela S E 1983. Apartheid: South African Naziism. London: SCM.

Nolan A 1988. God in South Africa. Cape Town: David Philip.

Vally S 1999. Sunday World Opinion/Analysis. August 29:15

Villa-Vicencio C 1986. Theology and Violence. Johannesburg: Skotaville.

Sachs A 1990. Protecting Human Rights in a New South Africa. Cape Town: Oxford University Press.

United Nations 1978. The International Declaration of Human Rights. 